\title{
Democratic Values of Mongolians Becoming as a Pillar of Perspectives of Democracy, Human Rights, Freedom, and Legitimacy
}

\author{
Khatanbold Oidov \\ Mongolian Academy of Sciences, Ulaanbaatar, Mongolia
}

\begin{abstract}
The modern democracy in Mongolia has changed from ideology and desires into the daily actions and real-life needs of achievement of the people. The content of this article aimed to categorize the democracy development process and its challenges and opportunities in promoting democratic governance in Mongolia; such brought specific approaches of the changes and difficulties. The content of research article contextual approaches are characterized by own individual research data on democracy as basis on the use of the work and the independent research findings of the researcher. On the overview of process of uncut democracy consolidation, the democracy development in Mongolia managed to the most consistent principles and fundamental values of democracy up to second half of the 1990s. From the second half of the 1990s till the election in 2004, within this term, the following challenges and difficulties risen to action of slowing down that forming of political parties, grouped into fractional, blockage of post-trafficking, conspiracy, and to be corrupted and bribery as mentioned as newly adverse phenomena have begun to the democracy development.
\end{abstract}

Keywords: democracy, human rights, legitimacy, blockage, Mongolia, rule of law, democratic governance, human rights, national specifics, democratic values, Constitution of Mongolia

\section{Introduction}

\section{Defining the Research Background}

The 20th century is of paramount importance for the history of mankind; one and several countries have been choosing by the development which is based on the democratic values and main beliefs at the same time, and that have commenced by the beginning of transition to the future development through a way of evolution and revolution. This process is originated from the $21^{\text {st }}$ century, and democracy wave which studied takes place at the level of the diversity issues at the moment.

The countries that switched to democracy in the level of the first two waves of democracy have began to emerge from the same circumstances in general environment, such as economic and political conditions, while the third wave of democracy has changed into differentially, and formed by the following conditions.

For an instance, since the transition to the democracy designed by the process of globalization, the proceedings of the various forms of democracy and the transitional process have become common entrance,

Khatanbold Oidov, Doctor of Political Science, Academic Researcher from the Institute of Philosophy, Mongolian Academy of Sciences, Ulaanbaatar, Mongolia. 
and all of this should be a clear indication of global political processes. In other words, only non-state and international factors, such as historical, economical, social, and cultural aspects are influenced by the form of democratization, initiative commitment, and other entries of the democratic process. Today, any countries which apply to non-democratic regimes that the class is not unconnectedly as democratic political process of globalization, there are signs that commenced by the third wave of an independent democratic basis of international relations, which influenced by the social democratic movement and its substantial content more democratically efforts.

As considering of democracy referred as a proper values and main beliefs, establishment of the democracy problems has solidly defined as legitimate needs as not only required by a way of context of a pragmatic tool. Practically, the democratic institution has explained as solving the definite problems such related to the social and economic spheres. Ideally, democracy is considered as the needs of the people, rather than appropriated political regime in the current environment. The democracy, even if it is an economic crisis, has proved relatively stable.

\section{Objectives of Its Research}

Since the democratic regime has many scenarios, the following questions were associated with it. Now, it is globally accepted and recognized beliefs such adhering to judge the strengths and weaknesses of liberal democracy, as well as investigating that other forms of democracy expression as required that is essential for their tolerance. Political changes at the end of the 20th century would not be end with a process of democratization, then a history of democracy will not complete by it. In this sense, democracy is based on the idea of a combination of collapse and depression. In other words, while some countries are moving towards to democracy, some others may emerge from the democracy; then, the fourth wave of democracy is likely to be occur in the 21st century. Consequently, the attitude of predicting the development of new forms of democracy will prevail in the political theory.

Samuel Huntington (1997) explained by the above-mentioned that democratic character and its substantive analysis and approaches to the human being fully aware of that achieve the democratic movement back to the irreversible phenomena. Accordingly, most of the negotiations, surveys, and publications on democracy in Mongolia are in accordance with the concept of slogan under "democracy in Mongolia". The within political groups and political scientists were thanked and supported by this concept as constituted with an absolute majority. In the 20th century, the Mongols spoke, wrote, and studied on democracy. At first, it focused on the notion of "proletarian or socialist democracy" in Marxist theory, and then, it referred to escort on the idea of "liberal or free democracy" either nor Marxist theory. So, they were limited access to otherwise. Though, regardless of attempts to implement socialist democracy have failed to a standstill in the 1990s, and then the liberal democratic process reversed by the two decades, it was still remarked about the crisis in recent years, and somewhat it proceeded slowly (IPSL, SPAI, UNDP, 2006, 2008, 2010, 2013). Creative thinking is necessary spiritual quest questions about the future. This perspective is the firstly important to focus on the methodological issues (Tsanjid, Chuluunbaatar, \& Ganbat, 2008).

For instance, Mongolian researchers sensitively understood global diversity in the process of transition to democracy, and they mentioned those perspectives in the previous works of the main functions such listed on the articles. 
The basis of this social foundation was a new revolutionary democratic basis, that is not as feudal or capitalist, but as a socialist consciousness. This basis was the foundation of a new type of democracy, which was the privatization of the majority of workers who were privatized by minority of feudalists. (Jugder, 1958, p.31)

Academic Ch. Jügder (1958) explained that our revolution of the people is based on its own nature and a new type of democratic revolution against imperialism and feudalism, as well as non-capitalist development goals in connection with the non-democratic capitalist revolution, and the goal of development resisted and served on a unique background of contact cannot be fulfill socialist economic goals, such as "layers explained that essentially characterized by the state of its components foundation, in regards to the operational characteristics". In addition, the foundation of that time could not be understood in any independent society, and "it proposed to aiming to renovate that colony and the lagging feudal society into the new democratic society" with a revolutionary-democratic context, that should be prepared the transition to socialism and future trends of the "new democratic organization" (Jügder, 1958, p.31) as he noted down. Dr. Dashjamts emphasized that it is the definition such reflected by the distinctive specialties of our democratic revolution in modern functions (Dashjamts, 1978). He (Dashjamts, 1978) also examined that recent transformation of this phenomenon, the democratic revolutionaries, and workers of our national population rose steadily on the basis (Dashjamts, 1974) of the revolutionary democratic ideology and democratic revolution of the national democratic revolution in Mongolia in regards to the conclusion that played a significant role in the future of democratic revolution in striving to the development (Dashjamts, 1974). In addition, the social, economic, and social conditions and intellectual transition to a socialist revolution in the democratic revolution in the previous society of this country had a common determination in the face of objective and subjective difficulties; the main point of view is that success will be important for the realization (Dashjamts, 1978) of specific living conditions in Mongolia. The scholar, F. Fukuyama, emphasized that a modern state concentrates and deploys power to enforce rules on an impersonal basis. And state building is characterized by the struggle of politics to rise beyond family ties and create a neutral system explained by Fukuyama (2014) in accordance with book as titled on State Building: Governance and World Order in the $21^{\text {st }}$ Century. In addition to the rule of law limits the power of government by establishing accepted rules of justice, which are higher than any individual who currently holds political power. The rule of law has its origins in organized religion, Fukuyama added, which created a set of rules with a legitimacy independent from that of the state. Accordingly, the legitimacy of a democratic state is based on the priority of the moral code, which is ultimately constructed with the democratic perfection of the law (Fukuyama, 2004). In accordance with the definition for Fukuyama, any attempts to control democracy, self-government, respect for human rights, as well as a little other attempt to control the people's idea are transformation rather than exclamation. There is of course no agreed on hierarchy of state functions, particularly when it comes to issues, like redistribution and social policy, most people would agree that there has to be some degree of hierarchy: States need to provide public order and defense from external invasion before they provide universal health insurance or free higher education (Fukuyama, 2004).

\section{Results and Its Discussion}

In this sense, Mongolia's democracy is unique and undoubtedly traditionally, since it is associated with relevant research and assessments based on globalization; country's development policy and the situation in modern society should be taken into account of modern Western theory and concepts of democracy. Subsequently, spitting image of the socio-political lives cannot be separated by the assumption understanding 
of rights and wrong formation and deformed and exclusion circumstances of the liberal-democratic values.

Therefore, the Mongols, but we need to develop what society has performed in the last 25 years, and everyone has the freedom of speech and expression of their opinion such highlighted on the Constitution of Mongolia, as we attempt to clarify the situations of today's point of view to explaining the following concept on "humanitarian, civil, and democratic society". As far as we know, we have never even described by this concept of "building a democratic society of a humanitarian and civil democratic society" that proclaimed in the introduction to the Constitution of Mongolia. In this sense, we expressed our opinion on the basis of the results of this research in comparing to the ideas that presented by Mongolian and Western scholars' accepted wisdom with modern ideology of humanitarian, civil, and democratic society.

With regard to human rights, freedoms, and the rule of law, it considered as democracy as a value and status. This is a system of rights, because it is an integral part of democratic political institutions (Dahl, 2004). Respect for law and maintenance of power is the most important materials that make up the democratic process. Like other rights in a democratic process, the right to freedom of expression reflects with the moral independence and value of its own status and dignity.

Every citizen has a clear or rational understanding of the problems facing him/her; and regarding to this opinion is to choose a representative to work in order to defend on your ideas in a democratic country, trying to undermine the uncertainty through the theoretical theory that exists today.

In other words, the main task of the people is to create a proxy object for the construction of the government or the executive branch. In particular, democratic approach is an institutionalized procedure for the adoption of political decisions, when a person decides to get power over the crucial decisions to the public. Of course, the economic and social problems will not be solved by a marked improvement and expansion of democratic opportunities. But it expands the public consultation, the extent and previously marginalized groups, and participation in public life and the sense of the ability of the community. As the government increases, the deepening of democracy, and the expansion of innovative elements, many see social problems and improvement of judges peak level prisoners, selected officials to determine the probability of increasing the quality in legitimacy (Academy of Political Education , 2006).

As noted above, this can affect broader skills and create more widespread efforts that can direct all social life within their political participation of citizens. The purpose of this life is to involve citizens in their voluntary and social activities as citizens, express their views, communicate, cooperate, mitigate any conflicting climatic conditions, create conditions for cooperation, support them, reduce negative attitudes, improve democracy and strengthen political participation of others, provide an economic environment and democratic stability, and create a favorable environment for social issues. It is important. If we could not learn more than the current democracy, it is not a way to make a social commitment and orientation (Batchuluun, 2003). Therefore, the opinion of the Mongolian state is that, in fact, when we are in political interaction and not in direct participation in the government, we respect for the law and any form of protest, mainly because of the impractical tradition of tradition, circumstances (Batchuluun, 2003).

Thus, the quality and value of democracy are not always the mechanism of demarcation, and not a complex system that requires itself, so this can be seen in some positive models. For example, democracy can bring wealth to people's lives, as well as learn political freedom, economic needs, freedom, and democracy. Political freedom is a part of human freedom, and the exercise of civil and political rights is an integral part of a good life in human society. It is important that political and social participation be valuable for the benefit of 
the individual. Democracy itself plays a significant instrumental role in encouraging others to promulgate their voice such people should motivate on the political expression. A detailed study of democracy, and democracy is a practical help to provide people with the opportunity to learn from each other, and establishing the social values and the formation of priorities. In this sense, democracy is inherently valuable in the lives of citizens, as well as in terms of instrumental importance of when making political decisions, in associated with constructive (Batchinluun, 2003) relevance of policy decision. In accordance with paragraph 2 of Article 14 of the Constitution of Mongolia, the values of democracy in Mongolia mean ".... person is exempted from race, ethnic origin, language, race, age, gender, social origin, status, property, profession and position, religion, belief or education should not be discriminated against. Everyone has a legal right...”.

In addition, the Constitution of Mongolia highlighted as

...strengthening of the country's independence, sovereignty and supports human rights, freedom, justice, national unity, inherited the sacred state, ethics, history, cultural traditions and respect for the achievements of human civilization, we strive to develop humanitarian and civil-democratic society in our homeland....

Constitutional Declaration armed of the Communist country Mongolian bureaucratic and centralized economy, the socialist rejection of democracy, freedom, justice, human rights, and respect respects collar is intended for a mature market economy and a democratic civil society in the history of a significant increase in cost to the Mongolian jewelry international course with a pitch. Despite political, socio-economic reforms hold the demands for time, in terms of interest from the political parties of prostrating to keep their power, that they have hand painted into the Constitution, such as strongly criticized by researchers.

In fact, the main goal of the Constitution is not only to ensure government officials and those who have the privilege to work on behalf of providing the conditions there act on the preference of their people.

Economists called as "agency costs" has emerged in a number of ways and types, such as government officials trying to chase for personal profit gain, sit down from work, or effort to strengthen his/her own political rights, and any parties or officials shall presume to maintain its power and authority beyond the jurisdiction mandatory period.

In other words, the damage to society through the use of government officials in a position to benefit from a source of corruption. Ideally, the Constitutional institution, such as the distribution of power set the term of office, establishing the anti-corruption committee, as well as the concepts are designed to limit the possibility of seeking such government benefits. Consequently, the Constitution should contain a sanction mechanism to control the activities of state bodies and the release of guilty persons from post-election, and penalties for criminal or civil liability or restriction of powers (UNDP, Parliament of Mongolia, 2015). In this regard to reduce the possibility of "to act freely" in the government, governments are complying with laws and regulations, and the court is an important rule of law creates the conditions for independent of law enforcement. This shows that it is not only created by the political institutions, but also limits their "arbitrary opportunities", and regards to making analysis on the government's good practices whenever governments' change is very important action.

In addition, it is expected that corruption will be prevented by adopting a decree on limitation to reducing corruption with the participation of high-ranking civil servants and civil servants in the Constitution as allows the authorities to implement it. In addition, making the restriction of the possibilities of arbitrary in the government will allow authorities to implement it. 
In other words, the strengthening the legal system is the framework of importance. It is important to distribute powers to the state branches by defining the responsibilities, providing the sufficient financial resources, and having sufficiency trained and responsible staff. It ensures the independence of the judiciary, resolves the any type of criminal and civil cases in through fair and effectively, ensures the sovereignty of citizens in the following status of economic and socio-political prestiges, and increases the control of the role of fair trial in the public approaches to delaying the inevitable goal. In addition, the civil society organizations (CSOs) takes an action into the public legal entities that benefit public interests, reducing a bureaucratic red tape, and simplifying the law and allowing the private sector to operate effectively, and allows the private sector to operate efficiently as required by important factual setting in the tax and business legal environment.

In this way, the value of the state of existence will be a pillar of human rights, freedom, and legitimacy aimed at promoting democratic values of Mongolians in due to the implementation of market mechanisms such required factors of national independence, security, economic freedom, and environmental protection in the standing for the democratic values of supporting the implementation of devices.

With regard to the varieties of the democratic regime, the changes in the perception, and understanding of democracy in Mongolia, the 20th century is full of important historical process for Mongolia, and the mission of these processes has been linked to national sovereignty and national independence policy. The policies from the outsiders who being in power sought to stir up their policies are dominated by the challenges to the democratic progressive conservatives and intellectuals headed towards to the political, economic, and military activities against the people of Mongolia, and the time of factors were powerless, but the processes in the 1911 and 1921 were remained by their own spots in the national development process in Mongolia. Since 1921, the People's Government marked by the national independence within the integrated system to ensure the Soviet Union, then the political, ideological, and economic protection of the security was based on the teachings of Marxism-Leninism theory of social development integration within the resolve of national independence and socialist behaviors for 70 years.

However, we can understand that the independence of Mongolia depends on the independence of the people and the individual's ideology. The democracy, such as the boundaries performed in 1989-1990 in Mongolia has given the possibilities of changes in the social mentality and further development of renovation of the social developments in Mongolia. In the context of this subject matter, we all know the democracy beyond the today's liberal values and meaning. For example, the process of creating a Republican Government in Mongolia, which began with the People's Revolution of 1921, that has manifested by the beginning of the alternation of lives and the lives of people in Mongolia. At that time, for the first time in the history of Mongolia, the law governed by the people who relied on, and in 1924 constituted by the Constitution, there was a sense of significance in understanding the significance of the Mongols in terms of democracy.

For example, the property has prioritized by the socially, action as socialized, action and privatization as transferring the actions, but in the process of namely realized by nationalization (niigemchlel) and privatization, and that the same people in power who transfers their power such named as a process of democratization of democracy. The term "democracy" was described as a reflection of the communist theory and concept of the Mongols over the past 70 years, and democracy is defined as a revolutionary process of transferring the power of a nobleman, monk, and ruler of wealthy sides to social unrest and ordinary people. The constitution of 1924 and 1940 proclaims that "...the supreme power of the real state authorizes by the peoples" (People's Great Khural, 1924), or “...the power of the real state...occupation of rural and urban workers” (People's Great Khural, 
1940) is clear that the power of authority has been linked to a class of social groups. Therefore, the state operational has emphasized the importance of the State of the People's Republic and the People's Government. The term "democracy" was introduced into the Constitution in 1960, and that was also used as a "people's democratic state" (People's Great Khural, 1960) according to the current theory and policy in that time. In the history of Mongolia, the term "democracy", which is reinforced by the theory of Marxist-Leninist theory, is the term of the democratic revolution that began in late 1989, that was largely based on the word of "ardchilal", not on the widely used a word of "democracy" as originated from the Latin language. The new Constitution adopted in 1992 stipulates that "democracy" in the liberal sense of the "humanitarian and democratic society" in shaping the mission of the consolidating the development. The democracy and the essence of the new constitution that has been enriched in the spirit of the Constitution over the past 30 years that has led to the vibrant desire and emotion from the daily lives of the people. Therefore, we needed to consider that start is exactly what democracy and that we must begin to strengthen.

Therefore, it is right to the universal essence of democracy from the point of view of research on the development of Mongolian democracy, and the democracy will begin to accept that socialized civilization and communication into the civilized human attributes (zurshmal) properties. As we assume that democracy as a human attribute, that is one of the most common ways of applying a democracy to any nation in the world; on the other hand, democracy first receives "outside" national achievements and experiences developed of a nation, and "winning (ideeshuulekh) the democratic values of its own land", that required as democracy development activities should reflect the combination of condensed process. When democracy is universal, it is more appropriate for democracy than "Democracy in Mongolia" or "Mongolian democracy", if it is a combination of "exogenous" and "self-everting" processes in the social relations of the country. Then, the factors that influence the development of democracy can be finishing as deceptive as the base and changes. Its fundamental factor is that democracy "manifests itself" in the context of the "sovereignty" of the land, as well as in conditions "out-of-state" as required by national conditions. Instead, factors of change can be considered as indicators of the phenomenon of "self-development" and "out of state" processes. However, factors of change can be considered as indicators of the phenomenon of "self-development" and "out-of-state" prevails with combination of state (IPSL, MAS, 2013).

\section{Conclusions}

Today's review of democracy shows that democratic governance has been in a crisis at all levels of the world, especially in regions, at local, national, and global levels. The crisis is due to the gradual closeness of some of the bad habits of ideology that are higher than the values, and non-principals higher than principles of truth and realism as well. This crisis is not just something, but only for the countries of the newly and restored democracy. It same applies to some of the oldest democracies that are involved in assisting democracies in emerging economies and restored countries. In the reconstruction of the country, the same is true for some of the old democracies that are involved in assisting democracies in emerging and restored countries. There are only a few democracies which have practically all democratic characteristics of democracy, but practically there is no value and democratic principle. In particular, post-conflict societies are still in the process of establishing the "a lesser amount of democracy" by the development organizations rather than their absence.

In this case, it is imperative note that UN Charter, the UN human rights treaties, conventions and national constitutions and other minorities notifies that democracy is defined as well. For example, the UN Charter does 
not contain provisions about "democracy", but the UN objectives to:

...to implement international cooperation in the promotion and assistance with a respect for the fundamental rights of all people without discrimination based on race, sex, language or religion to exercise international cooperation in promoting and promoting respect for the fundamental rights of all persons without discrimination in race, color, sex, language or religion.... (Paragraph 1.3)

"...to develop friendly relations in respecting the principles of equality and self-rule of nations between nations and countries..." (Paragraph 1.2) are defined as. Those goals of the United Nations represent in the fundamental principles and values of democracy.

These values are further enshrined in three UN human rights instruments and its named as the International Bill of Human Rights. In addition, the Universal Declaration of Human Rights stresses that links between democracy and human rights emphasized down "...human rights are protected by law in order to raise people against armed robbery and oppression...". This formula explains that the government should refrain from overthrowing or protecting the human rights under the law. In regarding to definition on the principle of governance at the Universal Declaration: “...the will of the people is the basis of the ggovernance..." and further more "...it will manifest itself in universal, fair and universal equality in elections..." (Article 21.3). The Universal Declaration emphasizes two main issues: “...everyone has the right to take part in governing the country through his direct or indirect representative..." (Article 21.1); and "...everyone has the right to public service in his country..." (Article 21.2). The recognition that democracy can contain labels of representatives of combining both of life and its participation can be a symptom of this.

Being a new economic and social system in the principles of equality and justice required as the nomadic way of life of Asians on the Asian heights, a different approach can be found to relations between the people and state which exists the civilization among the Mongols. A new system will capture the treasury of the best human material and intellectual culture (Maiskii, 2001).

Finally, if in some way, the seekers of the guilty disposition of the country's development prospects and socio-political features were somehow unable to be king, state minister, official, or army commander are will not be preperator, but only the Constitution which leads to the nation and humanity in the reflection the future humanity approaches.

In other words, while we would like to associate the "humanitarian and civil democratic society" which refers to smart, knowledgeable, and educated citizen, the proficient political institutions and consolidating the strong state with merit based civil service in regarding to engage to civic participation and active initiatives are guaranteed with building that citizen-centered humanitarian civil democratic society.

\section{References}

Academy of Political Education . (2006). Collection on democracy. (Tuya N, Trans.). UB: Academy of Political Education. Batchuluun, B. (2003). State and civic relationship in the post-communist society: Case of Mongolia. UB: Admon LLC. Dahl, R. A. (2004). On democracy. (Gankhuyag D, Trans.). UB: Admon LLC.

Dashjamts, D. (1974). Marxism and leninism as floursihed in Mongolia. UB: Admon LLC.

Dashjamts, D. (1978). Development of the Marxist Thinking in the People's Republic of Mongolia. UB: Admon LLC. Fukuyama, F. (2004). State building governance and world order in the 21st century. NY, Itaca: Cornell University Press. Fukuyama, F. (2014). State building Governance and world Order in the 21st Century. (Gombosuren. Ts, Trans.). UB: Admon LLC.

Huntington, P. S. (1997, October). Democracy's third wave. Journal of Democracy, 8, 6. 
IPSL, MAS. (2013). Social transformation in Mongolia: Academic collective book (Vol. II). (Chuluunbaatar G. Dash-Yondon B, Ed.). UB: Bembi San LLC.

IPSL, SPAI, UNDP. (2006, 2008, 2010, 2013). Change sin the demoratic governance in Mongolia. УБ.: Sansudai, Bembi-san LLC.

Jugder. C. (1958). Issues on the bacis and living grouping at the our transitional period. Issues on the "State and Legal Studies, (3), 31.

Maiskii, I. (2001). Modern Mongolia (Autonomous Mongolia at the beginning of XX century). (Otkhon Ts, Trans.). UB: Admon LLC.

People's Great Khural. (1924). Article 1, Constitution of Mongolia. Constitution of the Mongolian People's Republic. People's Great Khural. (1940). Article 3, Constitution of Mongolia. Constitution of the Mongolian People's Republic. People's Great Khural. (1960). Article 3, Constitution of Mongolia. Constitution of the Mongolian People's Republic.

Tsanjid, A, Chuluunbaatar, G, \& Ganbat, D. (2008). Democratic principle and integration on the national characteristics and culture. UB: IPSL, MAS, Association of Political Science of Mongolia.

UNDP, Parliament of Mongolia. (2015). Role of the Constitution of Mongolia in the consolidation of democracy: Analysis. UB: Bit Service LLC. 